It will have been seen that in the investigation of which $I$ have given an imperfect account, free scope has been "given to speculation, but that speculation has been governed and directed in every case by appeal to the numerical results of a dynamical problem, and $I$ therefore submit that it stands on a different footing from the numerous general speculations to which the nebular bypothesis has given rise.

\section{NATURAL SCIENCE IN HUNGARY IN THE LAST TEN YEARS}

FEW of the readers of NATURE are aware that Hungary has of late years become the scene of active efforts in science, and especially the natural sciences.

The following sketch of an article, written by Mr. Coloman Szily, member of the Academy of Sciences, and Professor of Physics at the Polytechnic of Budapest, and published in the Budapesti Sremli (Budapest Keview), may therefore not be altogether without interest.

The first active sign of native scientific life in this direction in Hungary was the founding of the Academy of Sciences in 1830. Up to that time there were single men of science, but no organised scientific life. But the chief object aimed at by the Academy was the cultivation of the national language, and the excessive zeal with which it pursued this aim did much harm to the cause of the natural sciences here. An erroneous attempt to substitute purely Hungarian words for the mathematical and other scientific expressions universally accepted elsewhere, threw great obstacles in the way of the progress of the natural sciences in our country.

This and other errors soon brought a reaction.

The "General Assembly of Physicians and Naturalists" was soon started amid general enthusiasm. The meetings of the assembly were held yearly in different cities from $184 \mathrm{I}$ up to 1848 , and then renewed in 1863 , after a cessation of fifteen years, caused by political events. A yearly report was issued, containing the various papers read at the meeting, as well as an account of physical characteristics of the district in which it was held.

Far more brilliant was the success reached in the cultivation and promulgation of the natural sciences by the "Termíszettudományi Társulat" (Society of Natural Sciences), which was started at the same time. By 1848 the number of the members rose to more than 400 . Its first yearly report was then issued, and a contract made for the starting of a scientific magazine, entitled "Magyar Iris." This powerful start, which was made independently of the Academy, and which proved of everincreasing importance, could not remain without effect. In 1844 a proposition that the two classes of mathematicians and naturalists might hold their meetings and carry on their financial and other operations separately from the rest was partialiy accepted. Some years later (r86x) it only required a single lecture (of Prof. Joseph Izabo's) to bring the whole Academy to pronounce a resolution against the attempt to Magyarise the nomenclature.

In the meantime the events of $1848-49$ were followed" by a long period of despotism, which tended to paralyze all attempts at association. The most distinguished men of science were forced off the field of action, the Academy could hold no meetings, the Society of Natural Sciences was on the brink of disso. Intion, its members were scattered, its collections had to be given away for lack of funds to pay the rent of the accommodation needed for them, and it was barely able within ten years to publish two of its yearly reports.

Between $185^{\circ}$ and 1860 the nation began to breathe more freely. Its very first efforts were turned towards the advancement of science. A very fine building was raised for the Academy, and its capital considerably increased, by means of private subscriptions. It thus became able to do much more than it did previously, both for the improvement of our native language and for the cultivation of the various branches of science. In.1860 it appointed a committee of mathematicians and naturalists, whose duty it was to explore the whole country and give an account of its natural and technical features. Ever since the year 1868 Government has devoted the yearly sum of 5,000 florins to the furtherance of the labours of this committee. But this sum frequently proves insignificant. Fourteen volumes of the publications of the committee, entitled, "Scientific Treatises Relating to Home Topics" (Termiszettudományi közleménysk, vonatkozólag a hazai viszonyokra), edited by its secretary, Prof. Joseph Szabo, have already appeared. At the same time with this the Academy started a second series of periodicals for publishing mathematical and scientific treatises, not confined to topics within the limits of our country. They appeared yearly from 1860 to 1867 , six volumes in all.

After the renewal of constitutional life in 1867 our naturalists were also filled with a strikingly-increased zeal for labour. The Academy has up to the present day issued thirty-two volumes in all. Many articles, treating of the original researches of our naturalists, have appeared in foreign periodicals. The meetings of the department of natural sciences in the Academy have of late borne witness to a truly diligent and scientific spirit, there scarcely being one in which less than six or eight treatises have been presented upon topics of original research.

In $\mathrm{I} 868$, though no preliminary agreement had taken place between the two institutions, the department of Naturalists of the Academy, having arrived at the conviction that the popularising of the natural sciences was not their calling, abandoned the attempt, and decided that they should henceforth direct their efforts solely to the cultivation of the sciences and the making of scientific researches in our country, while the Society of Natural Sciences took upon itself the spreading and popularising of them. To this end the Society started a monthly periodical; the number of members of the Society rising in the very first year of its exist. ence from 600 to $I, 600$, the second year to 2,200 , until at present it borders upon 4,800. A short time later the Society began to arrange lectures connected with experiments for the benefit of the public, These lectures have now been kept up for eight years, and the large lecture-hall in which they have been held has always been crowded with hearers. As long as it was possible these lectures were published in the Fournal of Natural Sciences; now, however, they appear in the form of a new series of publications under the title, "Collection of Popular Treatises upon Topics pertaining to the Natural Sciences." In 1872 the Society again started a new undertaking, namely, the translating into Hungarian and issuing of foreign works of a popular kind upon the natural sciences. The result of this undertaking, which has enjoyed the support of 1,500 subscriber: as well as a yearly aid from the Academy, has up to the present time been the issuing of twelve volumes, such as "Geologie der Gegenwart," by von Cotta ; Darwin's "Origin of Species," Helmholtz's " Populäre Vorlestungen," Huxley's "Lessons in Physiology," Lubbock's "Prehistoric Times," Proctor's "Other Worlds than Ours," and Tyndall's "Heat as Motion." An Anthology has also been compiled, containing a treatise from every scientific author who has contributed to the popularising of the natural sciences, from the time of Arago and Humboldt downwards, and a volume containing the complete works of the late Julius Greguss. These books always find a large number of purchasers.

But there is another branch of activity which is of more importance, perhaps, than all those, namely, its efforts for the encouragement of original research. From 1870 the legisla. ture of our country, in appreciation of the labours of the Society, has voted a yearly sum at first of 5,000 , and afterwards of 4,000 florins, for the promotion of such researches as stand most nearly connected with the interest of our country, and the publication of an account of the same. In this series of publications the following have appeared up to the present time :"The Rise and Fall of Tide in Fiume Bay," by Emile Stahl. berger: "The Ice Grotto of Dobsina," by Dr. Joseph Alex. ander Krenner; "Sketch of the Ligaridas of Hungary," by Dr. Géza Horváth; "The Spiders of Hungary: Vol. I. Generai Part," by Otto Hermann ; "The Iron Ores and Iron Products of Hungary, with Special Reference to the Pincipal Chemical and Physical Qualities of the Iron," by Anton Kerpsly.

In searching out and making known the physical characteristics of our country, the Society of Geologists (Magyar földtani társulat), founded in $185 \mathrm{I}$, can also boast considerable merits. The Society also publishes a monthly periodical under the title of Geological Reviuw.

In 1872 there was also a Geographical Society founded, which did not aim so much at the advancement of geographical researches as at keeping the public informed of any progress made on this field by means of a two-monthly review.

This active interest in the natural sciences is not confined only to our capital, but has taken root throughout the country. To prove this we have but to note the interest manifested in the labours of the Society of Natural Sciences in all grades of 
society everywhere, and the fact that societies under various titles, but all aiming at the cultivation of the natural sciences, were formed in many of our larger lowns as early as between $1850-60$, and more still of late years.

There is another circumstance worthy of notice, which affords perbaps a clearer illustration of the general interest in the natural sciences, and diligence on the field of the same, than even the rise and progress of the various societies already mentioned. It is the constant increase in the number of scientific periodicals, of which the following are already in circulation, besides the publications of the academy and the three societies of which we have spoken :-

(I) Nature (Természet), which appears every two weeks, and is now in the tenth year of its existence; (2) Polytechnical fournal (Mitessetemi lapok), a monthly periodical for mathematical and technical treatises; (3) Reports of the Meetings of the Society of Physicians and Natniralists in Klausenburg, started in 1876 ; (4) Botanical Papers, a monthly, started in $1877 ;(5)$ Leaves of Natural History, a quarterly periodical, started in 1877 , and edited by the Hungary National Museum. At the end of each volume is a review of the contents, written either in French or German, in order to be understood in foreign countries, and containing either a complete translation or an abstract of all the more important articles in the volume; (6) Magazine of Natural Sciences, a two-monthly periodical, started in 1877 , and edited in Temesvár by the Association of Naturalists of South Hungary.

To recapitulate briefly what has been said, there are in Budapest, besides the department of natural sciences in the Academy, three societies, the object of which is exclusively the cultivation of the natural sciences, and one of which is of dimensions that, considering the total number of inhabitants, are scarcely equalled anywhere in Europe. In other parts of our country we have in all six societies of naturalists, and there are in circulation nine scientific periodicals, not one of which enjoys any aid from the State, all being supported exclusively by the readers.

These societies, however, are not the sources of science, but merely, so to speak, its conducting pipes. The sources of it spring from the collections and laboratories of the universities. The progress made here of late years has also been considerable. Ou: university, which was greatly neglected up to the year 1850, has of late taken such a start forward that its condition of ten years ago is not to be compared to its present state. The number of professors' chairs pertaining to the natural sciences (including those of the University and the Polytechnic of Budapest, and the University of Klausenburg) now amounts to three times what it was previously. The greater part of these chairs are occupied by young professors, who have been educated at foreign universities, under the instruction of the most distinguished men of science. Each one has a respectable sum of money at his disposal for cabinet and laboratory purposes. Separate buildings have been raised and equipped as institutes of natural sciences, such as the Chemical and Physio. logical Institute, connected with the University, which stands under the direction of Prof. Charles Than, and already enjoys a wide-spread renown in Europe. The buildings intended for a clinic are nearly completed, and soon the Institute for Mysics, the Mineralogical and Zoological Institute, and the buildings of the Polytechnic will be raised in their turn. The number of the students of philosophy increases with striking rapidity, and some of the most distinguished of these are yearly sent out to foreign universities at state expense, with a view to their afterwards accepting appointments in their own country.

All these things clearly show that Hungary has within the last ten years made striking progress in the field of natural sciences, so that the distance which separated her in this respect from her western neighbours, has grown palpably less. Would that providence should permit her to continue the work thus begun :

J. M. A.

\section{PUBLISHERS' ANNOUNCEMENTS}

MESSRS. WILliam BrackWOOD AND SoNs announce "The Transvaal of To-day: War, Witchchraft, Sport, and Spoils in South Africa," by Capt. Alfred Aylward, late Commandant, Transvaal Republic. Capt. Aylward commanded the Leydenberg volunteers on the Boers' frontier until the Republic was annexed by the British, and from the prominent part he played in Transvaal politics, as well as from his knowledge of the country and his experience of Kaffir warfare, his book may be expected to throw some light upon questions that are now attracting public attention.

Messrs. Kegan PaUl and Co. announce that they will add to their International Scientific Series in October, a "History of the Growth of the Steam Engine," by R. H Thurston, Professor of Mechanical Engineering in the Stevens Institute of Technology, Brooklyn. The volume will give a history of the discoveries, inventions, and many ingenious experiments that gradually led to the success of the steam engine in the last century, and will be illustrated with fifteen portrait and 148 engravings on wood. This work will be followed speedily by Prof. Huxley's volume on "The Crayfish : an Introduction to the Study of Zoology." Prof. Alexander. Bain's "Education as a Science;" and Dr. H. Charlton Bastian's treatise on "The Brain as an Organ of Mind." Two translations from the French will also be included in the series before Christmas, namely, "The Human Race," by Prof. A. de Quatrefages, and "The Brain and its Functions," by Dr. J. Luys, The same publishers announce "The Geology of Ireland," by G. Henry Kinahan, M.R.I.A., \&c., of Her Majesty's Geological Survey; with numerous illustrations and a geological map of Ireland; to be ready in October. "Etna a History of the Mountain and its Eruptions," with mans and illustrations, by G. F. Rodwell, F.R.A.S., F.C.S. "Flowers and their Unbidden Guests," by Dr. A. Kerner, Professor of Botany in the University of Innsbruck; translation edited by W. Ogle, M.A., M.B.; with illustrations. "Mind in the Lower Animals in Health and Disease," by W. Lunder Lindsay, M.D., F.R.S.E., F.L.S., Hon. Member of the New Zealand Institnte; Vol. I. Mind in Health; Vol. II. Mind in Disease. "History of the Evolution of Man," by Prof. Ernst Haeckel, Author of "The History of Creation ;" two vols., with numerous illustrations. "Gaur: its Ruins and Inscriptions," by the Late John Henry Ravenshaw, B.C.S. ; edited by his Widow; with forty photographic illustrations, and fourteen facsimiles of inscriptions. These three last books will be ready for publication in November.

Messrs. Reeve AND Co. have just published the fourth edition of Bentham's " Handbook of the British Flora." The principal alteration in this edition has been the giving the first place to the Latin names of the genera and species. The attempt made in previous editions to establish an English scientific nomenclature, in imitation of the French and German ones introduced into several standard Continental floras, has, we regret to say, proved a failure.

Messrs. Macmillan and Co, will publish, in the course of the season, the following new books and new editions:-" Sport and Work on the Nepaul Frontier, or Twelve Years' Sporting Reminiscences of an Indigo Planter," by "Maori," with Map and Illustrations ; "Coal, its History and its Uses," by Profs. Green, Miall, Thorpe, Rücker, and Marshail, of the Yorkshire College, Leeds, with numerous Illustrations, 8vo; "Chemistry: a Treatise on," by Profs. Roscoe and Schorlemmer, of the Owens College, Manchester, vol, ii., "Metals," part I, 8vo ; "Gegenbaur's Comparative Anatomy," a Translation revised with Preface by Prof. E. Ray Lankester, F.R.S., with numerous Illustrations, medium 8vo; "A System of Medicine," Edited by J. Russell Reynolds, M.D., F.R.S, vol, v., completing the work; "Modern Realism Examined," by the late Prof. Herbert, Edited by Prof. James M. Hodgson; "Science Lectures at South Kensington," vol, ii., crown 8vo; "The Theory of Sound," by Lord Rayleigh, M.A., F.R.S., vol, iii., 8vo ; "Heat," an Elementary Treatise, by P. G. Tait, Professor of Natural Philosophy at Edinburgh, with numerous illustrations, crown 8vo; "Sound" (NATURE series): a series of simple, entertaining, and inexpensive experiments in the phenomena of sound, for the use of students of every age, by Alfred Marshall Mayer, Professor of Physics in the Stevens Institute of Technology, \&c., \&c. ; "Ismailia" by Sir Samuel W. Baker, Pasha, a narrative of the expedition to Central Africa for the suppression of the slave trade, organised by Ismail, Khedive of Egypt, with maps, portraits, and numerous illustrations by Zwecker and Durand, new and cheaper edition, one vol., crown 8vo; "A Ramble Round the World," by M. le Baron de Hiubner, formerly Ambassador and Minister, translated by Lady Herbert, new and cheaper edition with numerous illustra. tions, crown 8vo. 